\title{
Flavobacterium soli sp. nov., isolated from soil
}

Correspondence

Jung-Hoon Yoon

jhyoon@kribb.re.kr

Tae-Kwang Oh

otk@kribb.re.kr
Jung-Hoon Yoon, So-Jung Kang and Tae-Kwang Oh

Korea Research Institute of Bioscience and Biotechnology (KRIBB), PO Box 115, Yusong, Taejon, Korea

\begin{abstract}
A Gram-negative, rod-shaped Flavobacterium-like bacterial strain, DS- $6^{\top}$, was isolated from soil from the island of Dokdo, Korea, and subjected to a polyphasic taxonomic study. Strain DS- $6^{\top}$ grew optimally at $\mathrm{pH} 7 \cdot 0$ and $25{ }^{\circ} \mathrm{C}$ in the presence of $0-0.5 \%(\mathrm{w} / \mathrm{v}) \mathrm{NaCl}$. It contained MK-6 as the predominant menaquinone and iso- $\mathrm{C}_{15: 0}$ and iso- $\mathrm{C}_{17: 0} 3-\mathrm{OH}$ as the major fatty acids. The DNA $\mathrm{G}+\mathrm{C}$ content was $36.9 \mathrm{~mol} \%$. Phylogenetic analysis based on $16 \mathrm{~S}$ rRNA gene sequences indicated that strain DS- $6^{\top}$ belonged to the genus Flavobacterium. Levels of $16 \mathrm{~S}$ rRNA gene sequence similarity between strain DS $-6^{\top}$ and the type strains of Flavobacterium species were below $95 \cdot 4 \%$. Strain DS $-6^{\top}$ differed from some phylogenetically related Flavobacterium species in several phenotypic characteristics. On the basis of phenotypic and phylogenetic distinctiveness, DS $-6^{\top}$ (= KCTC $12542^{\top}=$ CIP $108840^{\top}$ ) was classified in the genus Flavobacterium as the type strain of a novel species, for which the name Flavobacterium soli sp. nov. is proposed.
\end{abstract}

The genus Flavobacterium, which belongs to the CytophagaFlavobacterium-Bacteroides group, was proposed by Bergey et al. (1923). At the time of writing, the genus comprises 34 recognized species, including the recently described species Flavobacterium antarcticum (Yi et al., 2005), Flavobacterium granuli (Aslam et al., 2005), Flavobacterium fryxellicola and Flavobacterium psychrolimnae (Van Trappen et al., 2005), and Flavobacterium denitrificans (Horn et al., 2005). In this study, we report on the taxonomic characterization of a Flavobacterium-like bacterial strain, DS-6 ${ }^{\mathrm{T}}$.

Strain DS- $6^{\mathrm{T}}$ was isolated from soil samples collected on the island of Dokdo $\left(37^{\circ} 14^{\prime} 12^{\prime \prime} \mathrm{N}, 131^{\circ} 52^{\prime} 07^{\prime \prime} \mathrm{E}\right)$, Korea, using the standard dilution plating technique at $25^{\circ} \mathrm{C}$ on nutrient agar (Difco). The morphological, physiological and biochemical characteristics of strain DS- $6^{\mathrm{T}}$ were investigated using routine cultivation on trypticase soy agar (TSA; Difco) at $25^{\circ} \mathrm{C}$. Cell morphology was examined by light microscopy (Nikon E600) and transmission electron microscopy using cells from exponentially growing cultures. Cells were negatively stained with $1 \%(\mathrm{w} / \mathrm{v})$ phosphotungstic acid and the grids were examined after air-drying with a Philips CM20 transmission electron microscope. Gliding motility was determined as described by Bowman (2000). The Gram reaction was determined using the bioMérieux Gram stain kit according to the manufacturer's instructions. Growth at various temperatures $\left(4-40{ }^{\circ} \mathrm{C}\right)$ was measured on TSA. To investigate tolerance to $\mathrm{NaCl}$, trypticase soy broth (TSB)

Published online ahead of print on 23 December 2005 as DOI 10.1099/ijs.0.64119-0.

The GenBank/EMBL/DDBJ accession number for the 16S rRNA gene sequence of strain DS-6 ${ }^{\top}$ is DQ178976. was prepared according to the formula of the Difco medium and $\mathrm{NaCl}$ concentrations were varied $[0,0 \cdot 5$ and $1 \cdot 0-5 \cdot 0 \%$ $(\mathrm{w} / \mathrm{v})$ at intervals of $1 \cdot 0 \%]$. The $\mathrm{pH}$ range for growth was determined in nutrient broth (Difco) that prior to sterilization was adjusted to various $\mathrm{pH}$ values $(\mathrm{pH} 4 \cdot 5-10 \cdot 5$ at intervals of $0.5 \mathrm{pH}$ units) by the addition of $\mathrm{HCl}$ or $\mathrm{Na}_{2} \mathrm{CO}_{3}$. Growth under anaerobic conditions was determined after incubation in an anaerobic chamber on TSA and on TSA supplemented with nitrate, both of which had been prepared anaerobically under a nitrogen atmosphere. Catalase and oxidase activities and hydrolysis of casein, gelatin, hypoxanthine, starch, Tweens 20, 40, 60 and 80, tyrosine, urea and xanthine were determined as described by Cowan \& Steel (1965). DNase activity was investigated as described by Cowan \& Steel (1965) using DNase test agar (Difco). Hydrolysis of aesculin and nitrate reduction were studied as described by Lanyi (1987). Hydrolysis of carboxymethylcellulose was tested as described by Bowman (2000) using TSA as the basal medium. The presence of flexirubin-type pigments was investigated as described by Reichenbach (1992). Congo red adsorption was determined as described by Bernardet et al. (2002). Sensitivity to antibiotics was tested on TSA plates using discs containing the following antibiotics: polymyxin B (100 U), streptomycin $(50 \mu \mathrm{g})$, penicillin $\mathrm{G}(20 \mathrm{U})$, chloramphenicol $(100 \mu \mathrm{g})$, ampicillin $(10 \mu \mathrm{g})$, cephalothin $(30 \mu \mathrm{g})$, gentamicin $(30 \mu \mathrm{g})$, novobiocin $(5 \mu \mathrm{g})$, tetracycline $(30 \mu \mathrm{g})$, kanamycin $(30 \mu \mathrm{g})$, lincomycin $(15 \mu \mathrm{g})$, oleandomycin $(15 \mu \mathrm{g})$, neomycin $(30 \mu \mathrm{g})$ and carbenicillin $(100 \mu \mathrm{g})$. Assimilation of various substrates, enzyme activities, and other physiological and biochemical properties were tested by using the API 50CHB and API ZYM systems (bioMérieux) according to the manufacturer's instructions. 
Cell biomass for DNA extraction and for isoprenoid quinone analysis was obtained from cultivation in TSB at $25^{\circ} \mathrm{C}$. Chromosomal DNA was isolated and purified according to the method described by Yoon et al. (1996), with the exception that RNase T1 was used in combination with RNase A to minimize contamination with RNA. The 16S rRNA gene was amplified by PCR using two universal primers as described previously (Yoon et al., 1998). Sequencing of the amplified 16S rRNA gene and phylogenetic analysis were performed as described by Yoon et al. (2003). Isoprenoid quinones were extracted according to the method of Komagata \& Suzuki (1987), and then analysed using reversed-phase HPLC and a YMC ODS-A $(250 \times$ $4.6 \mathrm{~mm}$ ) column. For fatty acid analysis, cell mass of strain DS- $6^{\mathrm{T}}$ was harvested from TSA plates after incubation for 3 days at $25^{\circ} \mathrm{C}$. The fatty acids were extracted and fatty acid methyl esters were prepared according to the standard protocol of the MIDI/Hewlett Packard Microbial Identification System (Sasser, 1990). The DNA G +C content was determined according to the method of Tamaoka \& Komagata (1984) with a modification that DNA was hydrolysed and the resultant nucleotides were analysed by reversed-phase HPLC.
Morphological, cultural, physiological and biochemical characteristics of strain DS- $6^{\mathrm{T}}$ are given in the species description (see later) or are shown in Table 1. The almost complete 16S rRNA gene sequence of strain DS- $6^{\mathrm{T}}$ determined in this study comprised $1471 \mathrm{nt}$, representing approximately $96 \%$ of the Escherichia coli $16 \mathrm{~S}$ rRNA gene sequence. Comparative $16 \mathrm{~S}$ rRNA gene sequence analysis revealed that strain DS- $6^{\mathrm{T}}$ was most closely phylogenetically affiliated to the genus Flavobacterium (Fig. 1). However, the $16 \mathrm{~S}$ rRNA gene sequence of strain DS-6 ${ }^{T}$ showed less than $95.4 \%$ similarity to those of the type strains of other Flavobacterium species (Fig. 1).

The results obtained from chemotaxonomic analyses were consistent with the phylogenetic affiliation of strain DS- $6^{\mathrm{T}}$ to the genus Flavobacterium. The predominant isoprenoid quinone detected in strain DS- $6^{\mathrm{T}}$ was menaquinone- 6 (MK-6) at a peak area ratio of approximately $93 \%$; this is consistent with other Flavobacterium species (Bernardet et al., 1996, 2002; Yi et al., 2005). The fatty acid profile of strain DS- $6^{\mathrm{T}}$ comprised (of those making up $>1 \%$ of the total fatty acids): branched fatty acids iso- $\mathrm{C}_{15: 0}(26 \cdot 6 \%)$, iso- $\mathrm{C}_{17: 1} \omega 9 c(9 \cdot 6 \%)$, iso- $\mathrm{C}_{15: 1}(6 \cdot 3 \%)$, iso- $\mathrm{C}_{16: 0}(4 \cdot 1 \%)$,

Table 1. Differential phenotypic characteristics of Flavobacterium soli sp. nov. and phylogenetically related Flavobacterium species

Species: 1, F. soli sp. nov.; 2, F. johnsoniae (data from Reichenbach, 1989; Bernardet et al., 1996); 3, F. denitrificans (data from Horn et al., 2005); 4, F. tegetincola (data from McCammon \& Bowman, 2000); 5, F. antarcticum (data from Yi et al., 2005); 6, F. flevense (data from Reichenbach, 1989; Bernardet et al., 1996). +, Positive reaction; -, negative reaction; ND, not determined; V, variable among references; $\mathrm{V}$, variable reaction. All species are positive for growth on trypticase soy agar and nutrient agar (not determined for F. denitrificans). All species are negative for urease, $\mathrm{H}_{2} \mathrm{~S}$ production (not determined for F. denitrificans) and indole production.

\begin{tabular}{|c|c|c|c|c|c|c|}
\hline Characteristic & 1 & 2 & 3 & 4 & 5 & 6 \\
\hline Catalase activity & + & + & + & + & + & - \\
\hline Oxidase activity & + & + & - & - & + & + \\
\hline Flexirubin-type pigments & - & + & + & - & - & - \\
\hline Growth on sea water media & + & - & ND & + & + & + \\
\hline Highest $\mathrm{NaCl}$ concentration (\%) tolerated & 2 & 1 & $<5$ & 5 & 4 & ND \\
\hline Acid produced aerobically from carbohydrates & - & + & - & + & + & - \\
\hline \multicolumn{7}{|l|}{ Degradation of: } \\
\hline Gelatin & + & + & ND & - & + & - \\
\hline Casein & - & + & ND & - & + & - \\
\hline Starch & - & + & ND & - & - & $\mathrm{V}$ \\
\hline Carboxymethylcellulose & - & + & ND & - & - & - \\
\hline Agar & - & - & ND & - & - & + \\
\hline Aesculin & + & + & ND & - & - & + \\
\hline DNA & - & + & ND & - & + & - \\
\hline Tyrosine & - & + & ND & - & - & - \\
\hline Nitrate reduction & - & $\mathrm{V}$ & + & - & - & $\mathrm{V}$ \\
\hline$\beta$-Galactosidase & - & + & ND & - & - & + \\
\hline DNA G $+\mathrm{C}$ content $(\mathrm{mol} \%)$ & $36 \cdot 9$ & 33 & $34 \cdot 6$ & 34 & 38 & 33 or 35 \\
\hline
\end{tabular}




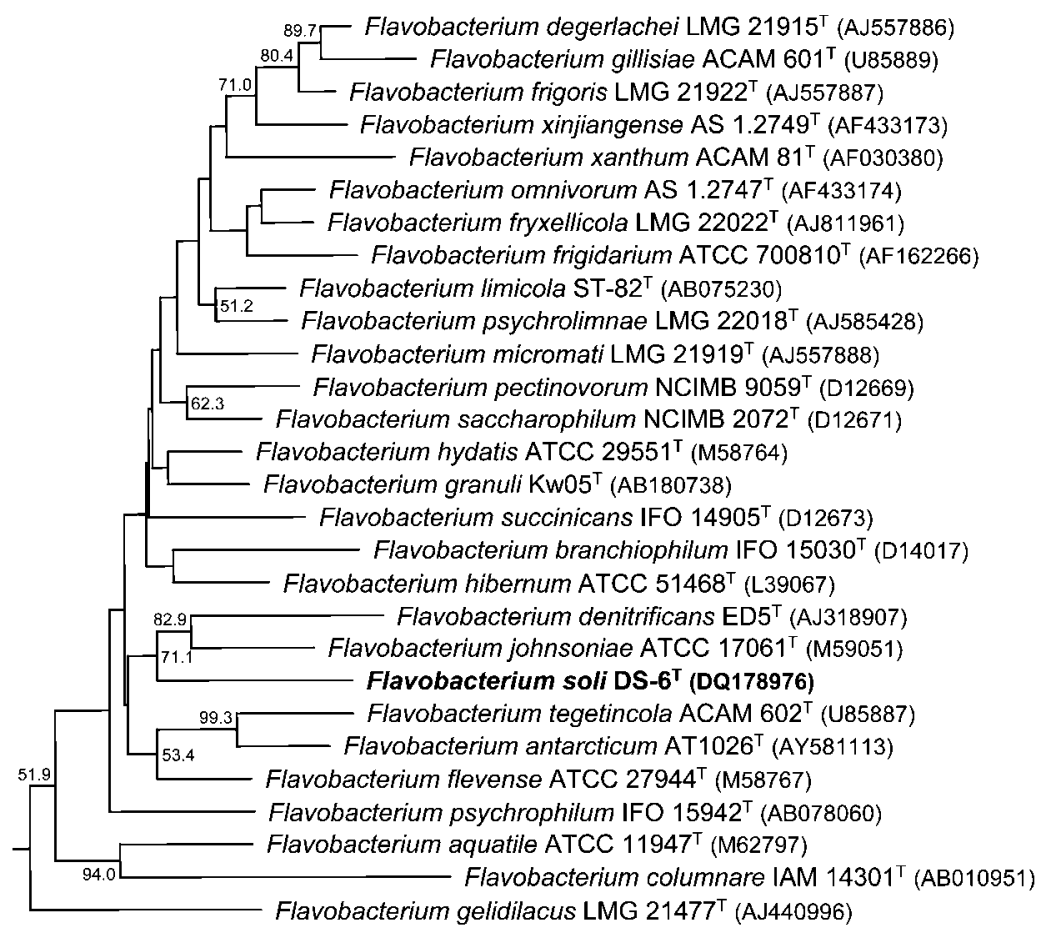

$\underline{0.01}$
Fig. 1. Neighbour-joining phylogenetic tree based on 16S rRNA gene sequences showing the position of Flavobacterium soli sp. nov. DS- $6^{\top}$ and of other Flavobacterium species. Bootstrap values (expressed as percentages of 1000 replications) of $>50 \%$ are shown at branching points. Cellulophaga lytica ATCC $23178^{\top}$ was used as an outgroup (not shown). Bar, 0.01 substitutions per nucleotide position. anteiso- $\mathrm{C}_{15: 0}(2 \cdot 7 \%)$ and iso- $\mathrm{C}_{16: 1}(1 \cdot 9 \%)$; hydroxy fatty acids iso- $\mathrm{C}_{17: 0} 3-\mathrm{OH}(11 \cdot 5 \%)$, iso- $\mathrm{C}_{15: 0} 3-\mathrm{OH}(6 \cdot 0 \%)$ and iso- $\mathrm{C}_{16: 0} 3-\mathrm{OH}(2 \cdot 5 \%)$; straight-chain fatty acids $\mathrm{C}_{15: 0}$ $(8 \cdot 2 \%)$ and $\mathrm{C}_{16: 0}(2 \cdot 0 \%)$; unsaturated fatty acids $\mathrm{C}_{15: 1} \omega 6 c$ $(1.9 \%), \mathrm{C}_{17: 1} \omega 6 c(1.4 \%)$ and $\mathrm{C}_{17: 1} \omega 8 c(1 \cdot 1 \%)$; and summed feature 3 comprising $\mathrm{C}_{16: 1} \omega 7 c$ and/or iso- $\mathrm{C}_{15: 0}$ $2-\mathrm{OH}(6 \cdot 0 \%)$. This fatty acid profile was similar to those of other Flavobacterium species, although there were differences in the proportions of some fatty acids, probably because of differences in cultivation conditions and extraction procedures (Bernardet et al., 1996, 2002; Aslam et al., 2005). The DNA G $+C$ content of strain DS- $6^{T}$ was 36.9 mol\%. Strain DS $-6^{\mathrm{T}}$ differed from phylogenetically related Flavobacterium species by several phenotypic characteristics, as shown in Table 1. Therefore, on the basis of the data presented, DS $-6^{\mathrm{T}}$ should be classified in the genus Flavobacterium as the type strain of a novel species, for which the name Flavobacterium soli sp. nov. is proposed.

\section{Description of Flavobacterium soli sp. nov.}

Flavobacterium soli (so'li. L. gen. n. soli of soil).

Cells are Gram-negative, aerobic rods $(0 \cdot 3-0 \cdot 6 \mu \mathrm{m} \times 1 \cdot 0-$ $3 \cdot 0 \mu \mathrm{m})$. No flagella are detected. Non-motile. Colonies on TSA are circular, slightly convex, smooth, glistening, creamyellow in colour and $2 \cdot 0-3 \cdot 0 \mathrm{~mm}$ in diameter after 3 days incubation at $25^{\circ} \mathrm{C}$. Optimal temperature for growth is $25^{\circ} \mathrm{C}$; growth occurs at 4 and $33^{\circ} \mathrm{C}$, but not at $34^{\circ} \mathrm{C}$. Optimal pH for growth is $7 \cdot 0$; growth occurs at $\mathrm{pH} 6.5$ and $8 \cdot 0$, but not at $\mathrm{pH} 6 \cdot 0$ or $8 \cdot 5$. Growth occurs in the presence of $0-2 \%(\mathrm{w} / \mathrm{v}) \mathrm{NaCl}$; optimal growth occurs in the presence of $0-0.5 \%(\mathrm{w} / \mathrm{v}) \mathrm{NaCl}$. No anaerobic growth occurs on plain TSA and on TSA supplemented with nitrate. Tweens 20, 40, 60 and 80 are hydrolysed, but hypoxanthine and xanthine are not. Congo red absorption is negative. Arginine dihydrolase, lysine decarboxylase, ornithine decarboxylase and tryptophan deaminase are absent. In assays with the API ZYM system, alkaline phosphatase, esterase (C4), esterase lipase (C8), leucine arylamidase, acid phosphatase and naphthol-AS-BI-phosphohydrolase activities are positive, but lipase (C14), valine arylamidase, cystine arylamidase, trypsin, $\alpha$-chymotrypsin, $\alpha$-galactosidase, $\beta$-glucuronidase, $\alpha$-glucosidase, $\beta$-glucosidase, $N$-acetyl- $\beta$-glucosaminidase, $\alpha$-mannosidase and $\alpha$-fucosidase activities are negative. Sensitive to penicillin G, chloramphenicol, cephalothin, novobiocin, tetracycline, lincomycin and oleandomycin, but not to polymyxin $\mathrm{B}$, streptomycin, ampicillin, gentamicin, carbenicillin, kanamycin or neomycin. The following substrates are utilized: L-arabinose, glucose, mannose, aesculin, cellobiose, maltose, starch, gentiobiose and 5ketogluconate. The following substrates are not utilized: glycerol, erythritol, D-arabinose, ribose, D-xylose, L-xylose, adonitol, methyl $\beta$-D-xyloside, galactose, fructose, sorbose, rhamnose, dulcitol, inositol, mannitol, sorbitol, methyl $\alpha$-Dmannoside, methyl $\alpha$-D-glucoside, $N$-acetylglucosamine, amygdalin, arbutin, salicin, lactose, melibiose, sucrose, trehalose, inulin, melezitose, raffinose, glycogen, xylitol, D-turanose, D-lyxose, D-tagatose, D-fucose, L-fucose, Darabitol, L-arabitol, gluconate and 2-ketogluconate. The predominant menaquinone is MK-6. The major fatty acids ( $>10 \%$ of the total fatty acids) are iso- $\mathrm{C}_{15: 0}$ and iso- $\mathrm{C}_{17: 0}$ 
3-OH. The DNA G $+\mathrm{C}$ content is $36.9 \mathrm{~mol} \%$ (determined by HPLC). Other phenotypic characteristics are given in Table 1.

The type strain, DS $-6^{\mathrm{T}}\left(=\right.$ KCTC $12542^{\mathrm{T}}=$ CIP $\left.108840^{\mathrm{T}}\right)$, was isolated from soil.

\section{Acknowledgements}

This work was supported by the 21C Frontier programme of Microbial Genomics and Applications (grant MG05-0401-2-0) from the Ministry of Science and Technology (MOST) of the Republic of Korea. We are grateful to the Ulleung County Administration and the Cultural Heritage Administration of the Republic of Korea for aiding access to Dokdo.

\section{References}

Aslam, Z., Im, W.-T., Kim, M. K. \& Lee, S.-T. (2005). Flavobacterium granuli sp. nov., isolated from granules used in a wastewater treatment plant. Int J Syst Evol Microbiol 55, 747-751.

Bergey, D. H., Harrison, F. C., Breed, R. S., Hammer, B. W. \& Huntoon, F. M. (editors) (1923). Bergey's Manual of Determinative Bacteriology. Baltimore: Williams \& Wilkins.

Bernardet, J.-F., Segers, P., Vancanneyt, M., Berthe, F., Kersters, K. \& Vandamme, P. (1996). Cutting a Gordian knot: emended classification and description of the genus Flavobacterium, emended description of the family Flavobacteriaceae, and proposal of Flavobacterium hydatis nom. nov. (basonym, Cytophaga aquatilis Strohl and Tait 1978). Int J Syst Bacteriol 46, 128-148.

Bernardet, J.-F., Nakagawa, Y. \& Holmes, B. (2002). Proposed minimal standards for describing new taxa of the family Flavobacteriaceae and emended description of the family. Int J Syst Evol Microbiol 52, 1049-1070.

Bowman, J. P. (2000). Description of Cellulophaga algicola sp. nov., isolated from the surfaces of Antarctic algae, and reclassification of Cytophaga uliginosa (ZoBell and Upham 1944) Reichenbach 1989 as Cellulophaga uliginosa comb. nov. Int J Syst Evol Microbiol 50, $1861-1868$.

Cowan, S. T. \& Steel, K. J. (1965). Manual for the Identification of Medical Bacteria. London: Cambridge University Press.

Horn, M. A., Ihssen, J., Matthies, C., Schramm, A., Acker, G. \& Drake, H. L. (2005). Dechloromonas denitrificans sp. nov., Flavobacterium denitrificans sp. nov., Paenibacillus anaericanus sp. nov. and
Paenibacillus terrae strain $\mathrm{MH} 72, \mathrm{~N}_{2} \mathrm{O}$-producing bacteria isolated from the gut of the earthworm Aporrectodea caliginosa. Int J Syst Evol Microbiol 55, 1255-1265.

Komagata, K. \& Suzuki, K. (1987). Lipids and cell-wall analysis in bacterial systematics. Methods Microbiol 19, 161-203.

Lanyi, B. (1987). Classical and rapid identification methods for medically important bacteria. Methods Microbiol 19, 1-67.

McCammon, S. A. \& Bowman, J. P. (2000). Taxonomy of Antarctic Flavobacterium species: description of Flavobacterium gillisiae sp. nov., Flavobacterium tegetincola sp. nov. and Flavobacterium xanthum sp. nov., nom. rev. and reclassification of [Flavobacterium] salegens as Salegentibacter salegens gen. nov., comb. nov. Int J Syst Evol Microbiol 50, 1055-1063.

Reichenbach, H. (1989). Genus Cytophaga Winogradsky 1929. In Bergey's Manual of Systematic Bacteriology, vol. 3, pp. 2015-2050. Edited by J. T. Staley, M. P. Bryant, N. Pfennig \& J. G. Holt. Baltimore: Williams \& Wilkins.

Reichenbach, H. (1992). The order Cytophagales. In The Prokaryotes. A Handbook on the Biology of Bacteria: Ecophysiology, Isolation, Identification, Applications, 2nd edn, pp. 3631-3675. Edited by A. Balows, H. G. Trüper, M. Dworkin, W. Harder \& K. H. Schleifer. New York: Springer.

Sasser, M. (1990). Identification of Bacteria by Gas Chromatography of Cellular Fatty Acids. Newark, DE: MIDI.

Tamaoka, J. \& Komagata, K. (1984). Determination of DNA base composition by reverse-phase high-performance liquid chromatography. FEMS Microbiol Lett 25, 125-128.

Van Trappen, S., Vandecandelaere, I., Mergaert, J. \& Swings, J. (2005). Flavobacterium fryxellicola sp. nov. and Flavobacterium psychrolimnae sp. nov., novel psychrophilic bacteria isolated from microbial mats in Antarctic lakes. Int J Syst Evol Microbiol 55, 769-772.

Yi, H., Oh, H.-M., Lee, J.-H., Kim, S.-J. \& Chun, J. (2005). Flavobacterium antarcticum sp. nov., a novel psychrotolerant bacterium isolated from the Antarctic. Int J Syst Evol Microbiol 55, 637-641.

Yoon, J.-H., Kim, H., Kim, S.-B., Kim, H.-J., Kim, W. Y., Lee, S. T., Goodfellow, M. \& Park, Y.-H. (1996). Identification of Saccharomonospora strains by the use of genomic DNA fragments and rRNA gene probes. Int J Syst Bacteriol 46, 502-505.

Yoon, J.-H., Lee, S. T. \& Park, Y.-H. (1998). Inter- and intraspecific phylogenetic analysis of the genus Nocardioides and related taxa based on 16S rRNA gene sequences. Int J Syst Bacteriol 48, 187-194.

Yoon, J.-H., Kang, K. H. \& Park, Y.-H. (2003). Psychrobacter jeotgali sp. nov., isolated from jeotgal, a traditional Korean fermented seafood. Int J Syst Evol Microbiol 53, 449-454. 